\title{
Reflections in Open Distance learning (ODL) through the lens Community of Inquiry (Col)
}

\author{
Thulani Zengele \\ Dept. of Educational Leadership and Management \\ College of Education, University of South Africa \\ tzengele@unisa.ac.za
}

\section{Doi:10.5901/mjss.2013.v4n13p455}

\begin{abstract}
More recently, attention has been given idea of Community of Inquiry. It is widely recognized that Community of Inquiry framework has become a prominent model of teaching and learning in online and blended learning environments. Despite the fact that much has been written about Community of Inquiry framework, it plays a critical role in serving as a framework for teaching and learning in ODL's online learning; and informs methodologies and approaches to course design and delivery. Drawing from the Community of Inquiry framework, this article reflects on the three structures, namely, social, cognitive and teaching presence with reference to ODL at the University of South Africa.
\end{abstract}

Keywords: Community of Inquiry Framework, Open Distance Learning, social presence, cognitive presence, teaching presence.

\section{Introduction}

The idea of a Community of Inquiry (Col) is increasingly permeating the Open Distance Learning (ODL) discourse. However, Community of Inquiry framework, developed by Randy Garrison, Terry Anderson and Walter Archer in 2000, is influential in explaining and prescribing the effective conduct of online learning. Among others, it provides a collaborativeconstructivist perspective to understanding the dynamics of online learning; and was first proposed to guide research on online learning. Like many ideas that encompass instinctive demand for ODL practitioners, the Col theoretical framework advocates that successful higher education experiences are supported by the presence and interaction of cognitive, social and teaching elements (Garrison, Anderson, \& Archer, 2000; 2001). For them, social presence, teaching presence, and cognitive presence are essential elements to foster successful educational experiences in computer-mediated higher education distance learning environments. The learning management system at Unisa is the Sakai which is popularly known as MyUnisa and it is a teaching and communication tool that is used by both lecturers and students. Notwithstanding the sudden increase of empirical research on online learning effectiveness, Col has become one of the principal models guiding research and practice in online higher education.

Theoretically, Col is consistent with the heritage of John Dewey and Matthew Lipman, an American educationist. Lipman's Col is based on dialogic argument and open-ended discussion. In addition, the idea of Col has its distant origins in the 1870s in Charles Sanders Peirce's conception of the worldwide scientific community of inquirers. Pierce sees a Col as closely related to a community of scientists. At its heart rests the supposition that effective online learning, especially higher order learning requires the development of community. Within this context, this article reflects on the Col framework and argues that all ODL online expressions are inherently social. It holds that reflective inquiry has practical value in providing meaning to ODL learning experience. Drawing from Randy Garrison, Terry Anderson and Walter Archer's work, this article conceptualises Col framework and captures the Col as social, cognitive and teaching presence. Lastly, it explores Col framework in Unisa's ODL context.

\section{What is Community of Inquiry framework?}

Perhaps, it is worthy indicating that the Figure 1 below captures what Col framework entails. This article sees Garrison and Arbaugh's (2007) work as a response to a "crisis" in post modern education settings. 
Fig. 1. Community of inquiry framework

\section{Community of Inquiry}

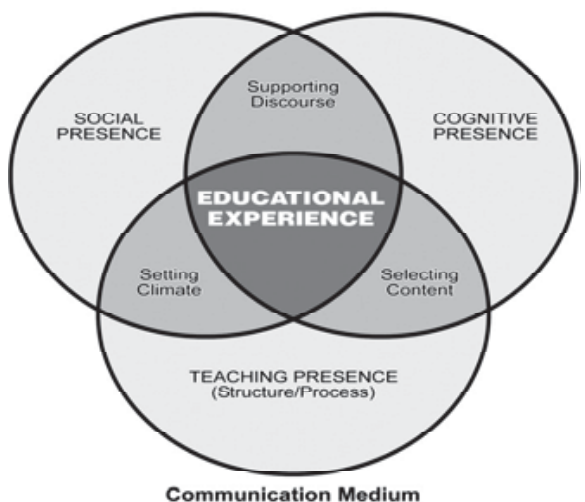

Source: Adapted from Garrison and Arbaugh, 2007

The concept "Community of Inquiry" is not very old. As Garrison, Anderson and Archer (2000) write, Col started more than two decades ago. There are reports that the first publication that was describing the Col framework including the social, cognitive and teaching presence was published (ibid). Soon after, according to research, there are more articles that detailed the methods for measuring each of the three elements already mentioned in this section regarding the Col framework, as well as another article detailing the various methodological issues that had to do with the framework itself (Rourke, Anderson, Garrison \& Archer, 1991; Garrison, Anderson \& Archer, 2001; Anderson, Rourke, Garrison \& Archer, 2000). Eventually, Garrison and Anderson (2003) embarked on the project of summarizing the seminal articles in a book which also investigated some of the practical implications of the framework and future research objectives.

At this point one should mention that the Col framework has since been espoused and modified by the various scholars working on Col throughout the world. The original articles and much of the successive work are archived at or linked from a website maintained by Randy Garrison at http://communitiesofinquiry.com/. The research group that created the Col framework worked together in the Faculty of Extension at the University of Alberta for a period of just five years, that is, from 1996 to 2001. Rourke, Anderson, Garrison and Archer, had known each other for about ten years before then, as they were all involved, although at the various universities, specializing in distance education in the province of Alberta, Canada. They acquired a research grant in 1997 that enabled them to resume with the process of validating their conceptual model (Garrison et al. 2009). Garrison $(1985,1989,2009 a)$ posits that Walter Archer had been conferencing and seemed to represent a completely new generation of distance education requiring new theoretical viewpoints. Since the Col framework was projected to offer a new theoretical perspective, it drew upon previous scholarship related to computer conferencing and/or content analysis from the 1980s and 1990s by a number of scholars including Henri (1991) and Newman et al. (1996; 1997). It also drew upon insights from the fields of linguistics and communications regarding relevant features of text-based communication as compared to spoken language. For Garrison, Cleveland-Innes, Koole and Kappelman (2006), the Col is a combination consisting of social, teaching and cognitive presence as shown in the diagram above. This same framework is also found to be consistent with the constructivist approaches found in the works of John Dewey. This paper attempts to first unpack each of the three elements as indicated above.

\section{Community of Inquiry as Social Presence}

A significant number of scholars like Garisson (2011; 2010; 2009), Gunawardena and Zittle (1997); Short, Williams and Christie, 1976) describe social presence as the moment when learners project themselves socially and emotionally. Taking this line of thought even further, Gunawardena and Zittle (1997) in this context, describe learners as real people. This paper aims to display whether the myUnisa system does indeed provide learners the opportunity for social presence or they only participate in ODL activities to submit assignments and view assignment and examination marks. However, some researchers argue that there is a strong relationship between social presence and learning outcomes (Arbaugh 2005; Hwang \& Arbaugh 2006; Williams, Duray \& Reddy (2006), Yo0, Kanawattanachai \& Citurs 2002). At the University 
of South Africa (UNISA) there are multiple modes of learning content delivery to assist learners to become active within the ODL system rather than as passive participants.

The use of satellite broadcasts provides the lecturer the opportunity to present learning content to multitudes of students situated in various centres and at the same time. Students are also accorded the opportunity to ask questions while answers are readily available and discussed, video conferencing are some of the modes of delivery that are facilitated by academic staff at Unisa. It is the same as satellite broadcasting excerpt that in video conferencing students can interact with the lecturer by engaging in discourse while at the end or during break in between the sessions the ODL practitioner can grant the students the opportunity to interact with one another and thus form communities. These are some of attempts that are driven at Unisa in order to create a conducive environment for learners in ODL settings to acclimatize with the benefits and merits of the online delivery mode. Anderson and Arbaugh (2004) concur that such an environment enhances the rapid masterly of the hidden curriculum.

Picciano (2002) also argues that social presence becomes less important when the learning activities are merely based on information acquisition without collaborative programmes based on group activity. This in the view of the author is likely to happen in those learning modules where there are no cooperative activities or portfolios. The Unisa 2015 strategy is geared towards the offering of all educational programmes online (www.unisa.ac.za). The Centre for Community Training and Development at UNISA offers the Advanced Short course in Outcomes-Based Assessment in Higher Education and Open Distance Learning. The objective of this programme was to prepare all lecturers to design learning and assessment programmes that would be relevant to the needs of ODL. It further focuses on acclimatizing the lectures on suitable assessment exercises that promote group learning which leads to social communities for higher order acquisition of skills.

This one year course was made compulsory in 2009 for all academics to attend and meet the prescribed requirements. However, this paper does not address the question of whether the Unisa academics apply the skills acquired from this programme. The question of whether ODL assessment skills are applied can be seen when the performance of ODL learners at Unisa is majored against expected outcomes. The emails to lecturers from students give an indication that students are active in the modules they are registered for. The emails of appreciation of lecturer's work due to the high standards of the module composition point to the desired outcomes having been reached.

Garrison and Arbaugh (2007) posit that social presence starts from interaction, a discourse and then the achievement of the feeling of comradeship. At Unisa there is a series of e-tutorial letters that are designed to engage the learners to academic programmes through the lecturers first introducing themselves then imparting knowledge in all aspects of the course. These e-tutorial letters are uploaded on to the myUnisa. As Garrison and Arbaugh (2007) argue that it is not easy to acquire trust and comfort, the Unisa video conferencing facility seems to be the best means of ODL delivery process that ensures learners get to view and verbally engage with the academics while having the opportunity to interact with other learners from other regions, provinces and countries to form a sense of community. For this mode of delivery to succeed, not only the learners have to be attuned to the operations but the academics as well need to rid themselves of technophobia.

\section{Community of Inquiry as Cognitive Presence}

Garrison and Arbaugh (2007) describe cognitive presence as the distinguishing characteristic of higher education as seated in John Dewey's construction of practical inquiry. For Garrison et al. (2001), the cognitive presence in terms of a practical model of inquiry leads to a four-phased process. The steps are a triggered event, exploration, integration and resolution (ibid). Some scholars (Celani \& Collins, 2005; Garrison \& Cleveland-Innes, 2005; Moore \& Marra, 2005), however, contend that cognitive presence is the most challenging to study and to develop online courses. This paper argues that during this stage of cognitive presence, the composition of the group becomes more important than the discussion format. In this sense, the author refers to situations where the group members do not share the same cultural capital to be able to form a valid sense of community.

South Africa is a country of stark contrasts where the poor access the same learning facilities side by side with the rich. The class groupings do not take into consideration the various socio economic conditions of learners. All learners are subjected to the same content and assessment forms despite their stark differences. In the author's view, the challenges encountered by learners from lower socio-economic backgrounds may not be the ones expected from them through increased efforts to participate in advanced ODL activities. At the same time, learners from affluent communities may experience challenges that could be emanating from their relaxed status in terms of competing for scarce resources for survival and this could be the acquisition of new learning content to enhance their socio-economic status. 
The other determinant of enhanced learner activity during this stage is the nature of the task itself. If it is problem or case based according to Garrison and Arbaugh (2007), the participants will not have a problem moving towards the resolution phase. The ODL practitioner is expected to be the leader and instructor of the learning process. To do this, the ODL practitioner should have a clear understanding of the developmental level of learners in the programme and the level of capacity to master programmes with sufficient effort. In South Africa, all forms of tests to determine the readiness of students are not allowed on grounds that they are discriminatory. Collaborative decision making needs proceed along the four stages, forming, norming, storming and performing as listed by Tuckman and Jensen (1977).

Using a practical inquiry model, Garrison and Arbaugh (2007) elucidated the four phases of developing cognitive presence: (1) identification of problem or issue that warrants further inquiry (Triggering Event), (2) exploration of a problem or issue through critical reflection and discourse, (3) learner construction of meaning from ideas developed through exploration (Integration), and (4) resolution where learners apply their new knowledge in other settings or contexts. The last stage is the one that guarantees the lecturer that in softer disciplines there is sense of masterly and cognitive presence since there is high degree of collaboration in soft disciplines. Garrison (2011:43) posits that cognitive presence is associated with learning and critical thinking. One approach to achieving this in an online environment is through case studies which "focus discussion from a real-world perspective that students can relate to" according to Garrison (2011: 90).

\section{Community of Inquiry as Teaching Presence}

Garrison and Arbough (2007) conceptualize that teaching presence consist of three components which are instructional design and organization, facilitating discourse and direct instruction. They contend that teaching presence is necessary for online learning to succeed. It is also regarded as a significant determinant for student satisfaction, perceived learning and sense of community. Anderson, Rourke, Garrison and Archer (2001) prefer the term "teaching presence" rather than "teacher presence" in their research because teachers often collaborate to achieve this role. The three components stated above are discussed in the following section of the paper.

\subsection{Instructional design}

Anderson et al. (2001) describe this as the planning and design of the structure process and evaluation aspects of the online course. The former Centre for Courseware and Development at the former Technikon Southern Africa which merged with Unisa in 2004 designed the highly interactive courseware design kit for academics to use when designing online teaching programmes. It comes as a complete kit consisting of a manual and a CD. There was no resounding success regarding the use of this kit since those who were supposed to train academics were not adequately skilled as well and academics still suffered from technophobia which problem still exists at Unisa to this day. Currently there are companies that provide training in instructional design for lecturers with a promise to give the lecturer a tablet or laptop as a gift for attending since these ITC elements will be issued after the training. The challenge at the moment is that the Human Resurces Department at Unisa does not allow Unisa attendees to receive tablets and or latops as gifts as they insist they are a bribe by these companies.

\subsection{Facilitating discourse}

Anderson et al. (2001) explain facilitating discourse as the means by which students become engaged in interacting about and building upon information provided in the course instructional materials. They say the component of teaching presence is consistent with findings supporting the importance of participant interaction in online effectiveness (ibid). This role has to do with sharing meaning, identifying areas of agreement and disagreement and seeking to reach consensus and understanding. Facilitating discourse means the instructor must review and comment upon student responses, raise questions and make observations to move discussions in a desired route. The instructor will also keep discussions moving smoothly and remove inactive students. These activities are important for graduate level management education where the emphasis is on developing team decision making skills.

\subsection{Direct instruction}

Anderson Rourke, Garrison and Archer (2001) postulate that direct instruction is the instructor's provision of intellectual 
and scholarly leadership in part through sharing their subject matter knowledge with students. This role needs a person that is adequately academically qualified to teach that module. Such an academic should be able to scaffold the learners' knowledge and raise it to a new level. Direct instruction is concerned with the indicators that assess the discourse and efficacy of the educational process. The instructor has to facilitate the discussions by presenting content using various means of assessment and feedback. This type of communication has a very high level of social presence or instructor intimacy as articulated by Anderson (ibid). The instructors must have both content and pedagogical know-how to make links among contributed ideas, make a diagnosis about the misperceptions and insert information from textbooks, articles and web-based materials.

As Hoskins and van Hoof (2005) observe, interaction and discourse play key roles in higher order learning but without structure and leadership with is also known as facilitation and direction. Without unambiguous leadership, students will employ in sequential monologues. Finegold and Cooke (2006) state that direction in the form of information resources, subject knowledge and discussion initiation was thought to be helpful. He further postulates that a strong and active presence of the instructor where there is active guidance and orchestration of the course is connected to both students' sense of connectedness and learning. Murphy (2004) says that in order for the highest level collaborative processes to occur within online asynchronous discussion, there must be explicit strategies aimed at promoting these processes. Gilbert and Dabbah (2005:14) conclude that the number and type of facilitator postings increase the level of interaction between students and they make it clear that structure and facilitation have a significant influence on discourse.

Another influence on the quality of the discourse and depth of learning may be metacognitive awareness. According to Campos, Laferrie and Lanpoint (2005:75-76), deep learning occurs when metacognitive procedures are in place. Metacognitive awareness is essential to effectively manage and monitor learning according to Garrison (2003). Teaching presence must not only increase interaction but must also help students to recognize the developmental progression of the inquiry process. Students enrolled for undergraduate programmes may not be sophisticated enough to distinguish between facilitation and direct instruction. Facilitation supports discourse with minimal shaping of the discussion. Discourse is disciplined inquiry that requires a knowledgeable academic who must manage the progression of the discussion ion a collaborative constructive manner. Direct teaching presence may also encourage and support student to gain an awareness of the inquiry process.

To end this section, direct instruction looks to the instructor as a subject matter expert, providing intellectual and scholarly leadership through in-depth learning (Anderson et al. 2001). According to Anderson et al. (2001), the teacher presents the content and questions; focuses the discussion on specific issues; summarizes the discussions; confirms understanding; diagnoses misconceptions; injects knowledge from diverse sources and responds to technical concerns. That is teaching practice at Unisa where the lecturer performs all the above functions while using the myUnisa system. These changes require educators "to acknowledge that learning can happen anywhere, whether in the formal classroom or the coffee shop; it should not be bound by time limits; and it must always yield measurable learning outcomes" (Gautsch \& Griffy-Brown, 2010: 32).

\section{Community of Inquiry Framework in Unisa's ODL Context}

Unisa's ODL fits thorough the lens Col framework. A sense of community drives people to form clusters and this is what attracts people to form groups and persevere in the various environments. It is therefore imperative that when Col is amalgamated into the ODL scenario, a sense of community could possibly improve on student retention and throughput rates. However, the author argues that there are vast social and educational communities that could affect the potential of community for education purposes. Unlike popular social websites like Facebook and Twitter educational communities are focused on learning in a social environment because of its flexible environment. In social communities, members tend to create their own network and they do this around commonalities.

The various social media such as social networking sites, video and audio sharing websites, wikis, and blogs offer online spaces where people interact, publish, collaborate, share, and communicate with others in virtual communities. At Unisa, the major social media tool is myUnisa. On myUnisa students are introduced to the modules they are registered for. Thereafter, all the learning materials are made available for the students in order to write and submit assignments which are also assessed by lectures using the Unisa onscreen marking system. Students are also able interact with their lecturers and among themselves. Students form discussion groups on myUnisa and collaborate when completing assignments. The system also allows them to access their assignment and examination marks. Unisa also has a system of satellite broadcasting and video conferencing facilities that are replacing the original group discussions. Group 
discussions benefitted only those students who resided next to developed places with transport facilities. The benefits of group discussions examination were also regarded as sessions where the examination scope was discussed with the lecturer concerned. They did not offer any benefit for students' interaction with other students.

Kujuk and Sahin (2013) posit that education plays an important role to meet the diverse needs of learners and improve their performance levels. Therefore, ODL institutions are expected to provide students and lecturers with the ICT equipment to access the internet sites like Google Scholar so that they may access new knowledge. In this manner, lecturers will be able to produce cutting edge knowledge that is in line with the current trends. Open and Distance education is geared towards the needs of those people in hard to reach places in order to remove distance from distance education. The business and intention of ODL is to conscientize those who already have access to ICT equipment and associated skills. In addition, Unisa has embarked on a massive progrmme of providing access to all registered students and staff to purchase tablets, laptops, and 3G internet access at drastically reduced prices. The service also provides free delivery of these ITC accessories. The website used for purchasing is called e solutions on Unisa's website www.unisa.ac.za.

Shin (2008) asserts that the most important aspect of the Col model is to bring both the lecturers and students to one social arena to discuss common aspects of the learning content. In this way, Shin (2008) says that this social interaction among students and teachers provides deep and meaningful learning environments in higher education, which can be either online or face-to-face. In the case of Unisa, students are likely to show improved results in terms of the acquisition of higher order skills. As Lazarevic (2011) puts it, the main purpose of social presence is to improve cognitive presence and increase critical thinking through educational transactions and communications among peers enrolled in an online course. Unlike popular social websites like Facebook and Twitter, socializing educational communities are focused on learning in a social environment. In social communities, members tend to create their own network and they do this around common interests. In contrast, in educational communities there must be a structure, leadership, and interaction among learners to be designed into a module in order to develop a sense of community among learners.

Garrison (2011) posits that in social websites the participants are inspired to use them because of their personal desires. To participate, Garrison (ibid) further states that in online learning communities, students may choose to enrol in a course but they may not necessarily want to take a required course in a programme or they also may or may not be fond of the idea of socializing in a classroom environment. The reason for the unwillingness could be the technophobic effects suffered by most lecturers and students at Unisa. At the same time, where lecturers are younger and residing in developed communities, there is a high degree of familiarity with ICT equipment use. When ICT equipment is properly used, learners that are enrolled in ODL institutions can be motivated to form communities.

\section{Conclusion}

As ODL is gradually becoming the preferred option for university education, the various Colleges within the University of South Africa will require an educational model to guide their online courseware design. The Col model with its focus on social, cognitive and teaching presence may be an educational structure for online and ODL practitioners. For example, academics have developed a rubric for intellectual supervision and a pattern for online course designers (Garrison, 2011). According to Shea et al.(2010), course designers can achieve presence by focusing on the entire course design, not just threaded discussions. Other researchers support the proposition that the Col framework is applicable in blended learning environments (Akyol et al. 2009); Arbaugh et al. 2008). This paper analyzed the Community of Inquiry framework from the three perspectives of social, cognitive and teaching presence and has attempted to demonstrate that if all ODL practitioners become aware of these three elements, a meaningful sense of community will be established to acquire higher learning skills in ODL environments. Yet, there is an inference from this paper that the Col framework could serve as an instructional design tool for ODL courses for a sense of community to prevail among students and lecturers. .

\section{References}

Akyol, Z. (2009). Examining Teaching Presence, Social Presence, Cognitive Presence, Satisfaction And Learning In Online And Blended Course Contexts. (PhD Thesis, Middle East Technical University).

Anderson, T., Rourke, L., Garrison, D. R., \& Archer, W. (2001). Assessing teaching presence in a computer conferencing context. Journal of Asynchronous Learning Networks, 5(2). Retrieved December 10, 2004, from http://www.aln.org/publications /jaln/v5n2/v5n2_anderson.asp. 
Arbaugh, J. B. (2005). How much does "subject matter" matter? A study of disciplinary effects in on-line MBA courses. Academy of Management Learning \& Education, 4, 57-73.

Arbaugh, J. B., Cleveland-Innes, M., Diaz, S. R., Garrison, R., Ice, P., Richardson, J. C., \& Swan, K. P. (2008). Developing a community of inquiry instrument: Testing a measure of the community of inquiry framework using a multi-institutional sample. Internet and Higher Education, 11(3-4), 133-136.

Campos, M. N., Laferriere, T., \& Lapoint, J. M. (2005). Analysing arguments in networked conversations: The context of student teachers. The Canadian Journal of Higher Education, 35(4), 55-83.

Celani, M. A. A., \& Collins, H. (2005). Critical thinking in reflective sessions and in online interactions. AlLA Review, 18, 41-57.

Finegold, A. R. D., \& Cooke, L. (2006). Exploring the attitudes, experiences and dynamics of interaction in online groups. Internet and HigherEducation, 9(3), 201-215

Garrison, D. R. (2011). E-learning in the 21st century (2nd ed.). New York: Routledge.

Garrison, D. R. (2003). Cognitive presence for effective asynchronous online learning: The role of reflective inquiry, self-direction and metacognition. In J. Bourne \& J. C. Moore (Eds.), Elements of quality online education: Practice and direction Vol 4 in the Sloan C Series. (pp. 29-38). Needham, MA: The Sloan Consortium.

Garrison and Arbough (2007) Researching the community of inquiry framework: Review, issues, and future directions. Internet and Higher Education 10 (2007) 157-172.

Garrison, D. R., \& Cleveland-Innes, M. (2005). Facilitating cognitive presence in online learning: Interaction is not enough. American Journal of Distance Education, 19(3), 133-148.

Garrison, D. R., Cleveland-Innes, M., Koole, M., \& Kappelman, J. (2006). Revisting methodological issues in the analysis of transcripts: Negotiated coding and reliability. The Internet and Higher Education, 9(1), 1-8.

Garrison, D. R., Anderson, T., \& Archer, W. (2001). Critical thinking and computer conferencing: A model and tool to assess cognitive presence. American Journal of Distance Education, 15(1), 7-23.

Gautsch, S., \& Griffy-Brown, S. (2010, November/December). The perfect blend. BizEd, 28-32.

Gilbert, P. K., \& Dabbagh, N. (2005). How to structure online discussions for meaningful discourse: A case study. British Journal of Educational Technology, 36(1), 5-18.

Gunawardena, C., \& Zittle, F. (1997). Social presence as a predictor of satisfaction within a computer mediated conferencing environment. American Journal of Distance Education, 11(3), 8-26.

Henri, F. (1992). Computer conferencing and content analysis. In A. R. Kaye (Ed.), Collaborative learning through computer conferencing: The Najaden papers (pp. 117-136). Berlin: Springer-Verlag.

Hoskins, S. L., \& van Hooff, J. C. (2005). Motivation and ability: Which students use online learning and what influence does it have on their achievement? British Journal of Educational Technology, 36(2), 177-192.

Hwang, A., \& Arbaugh, J. B. (2006). Virtual and traditional feedback-seeking behaviors: Underlying competitive attitudes and consequent grade performance. Decision Sciences Journal of Innovative Education, 4, 1-28.

Kucuk, S. and Sahin, I. (2013). From the Perspective of community of inquiry framework: an examination of facebook uses by preservice teachers as a learning environment. The Turkish Online Journal of Educational Technology, 12(2); 142-156.

Lazarevic, B. K. (2011). Examining the role of the introductory video in the development of teaching presence in online instruction. (PhD Thesis, The University of Nebraska-Lincoln). ProQuest Dissertations and Theses, http://search.proquest.com/docview /863490403?accountid=13654.

Moore, J. L., \& Marra, R. M. (2005). A comparative analysis of online discussion participation protocols. Journal of Research on Technology in Education, 38, 191-212.

Murphy, E. (2004). Recognizing and promoting collaboration in an online asynchronous discussion. British Journal of Educational Technology, 35(4), 421-431.

Newman, D. R., Johnson, C., Cochrane, C., \&Webb, B. (1996). An experiment in group learning technology: Evaluating critical thinking in face-to face and computer-supported seminars. Interpersonal Computing and Technology, 4(1), 57-74. Retrieved 2013/07/25, from http://www.helsinki.fi/science/optek/1996/n1/newman.txt.

Picciano, A. G. (2002). Beyond student perceptions: Issues of interaction, presence, and performance in an online course. Journal of Asynchronous Learning Networks, 6(1). Retrieved 2013/07/25 from http://www.sloan-c.org/publications/jaln/v6n1 /pdf/v6n1_picciano.pd

Anderson, T., Rourke, L., Garrison, D. R., \& Archer, W. (2001). Assessing Teaching Presence in Computer Conferencing Context. Journal of Asynchronous Learning Networks, 5(2), 1-17. Rourke, L., Anderson, T., Garrison, D. R., \& Archer, W. (2001). Methodological issues in the content analysis of computer conference transcripts. International Journal of Artificial Intelligence in Education, 12(1), 8-22.

Shin, J. K. (2008). Building an effective international community of inquiry for EFL professionals in an asynchronous online discussion board. (PhD Thesis, University of Maryland, Baltimore County). ProQuest Dissertations and Theses, http://search.proquest.com /docview/194075880?accountid=13654

Shea, P., Hayes, S., \& Vickers, J. (2010). Online instructional effort measured through the lens of teaching presence in the Community of Inquiry framework: A re-examination of measures and approach. International Review of Research in Open and Distance Learning, 11(3), 127-154.Retrieved July 6, 2011 from http://www.irrodl.org/index.php/irrodl/article/view/915/1650

Short, J., Williams, E., \& Christie, B. (1976). The social psychology of telecommunication. London: Wiley.Tuckman, B. W., \& Jensen, M. C. (1977). Stages of small-group development revisited. Group and Organization Studies, 2, 419-427. 
Yoo, Y., Kanawattanachai, P., \& Citurs, A. (2002). Forging into the wired wilderness: A case study of a technology-mediated distributed discussionbased class. Journal of Management Education, 26, 139-163.

Williams, E. A., Duray, R., \& Reddy, V. (2006). Teamwork orientation, group cohesiveness, and student learning: A study of the use of teams in online distance education. Journal of Management Education, 30, 592-616.

www.unisa.ac.za 